\title{
Spiritual remains: Hawai'ian funerary rituals and the legacy of Robert Hertz
}

Teri L. Sowell

\section{(2) OpenEdition \\ 12 Journals}

\section{Electronic version}

URL: http://journals.openedition.org/jso/788

DOI: $10.4000 /$ jso. 788

ISSN: $1760-7256$

\section{Publisher}

Société des océanistes

\section{Printed version}

Date of publication: 1 June 2007

Number of pages: 83-88

ISBN: 978-2-85430-010-9

ISSN: 0300-953x

\section{Electronic reference}

Teri L. Sowell, «Spiritual remains: Hawai'ian funerary rituals and the legacy of Robert Hertz », Journal de la Société des Océanistes [Online], 124 | Année 2007-1, Online since 01 June 2010, connection on 26 April 2019. URL : http://journals.openedition.org/jso/788 ; DOI : 10.4000/jso.788

(c) Tous droits réservés 


\section{Spiritual remains: Hawai'ian funerary rituals and the legacy of Robert Hertz}

par

Teri L. SOWELL*

\section{RÉSUMÉ}

Cet essai étudie les pratiques entourant la mort, la déification et la production de reliques dans la société traditionnelle de Hawai'i, en relation avec l'œuvre de Robert Hertz. Hertz a expliqué que cette croyance que la mort n'est pas instantanée, mais, plutôt, une procédure qui dure jusqu'à ce que le corps a atteint l'état de squelette. Ce processus produit des reliques qui peuvent être des objets puissants qui continuent de bénéficier aux vivants et permettent une certaine communication avec les défunts. Pour ce qui concerne l'Hawai'i traditionnel, on peut classer les reliques comme primaires (les os principaux), secondaires (les dents, les cheveux et de plus petits morceaux d'os) et tertiaires (les biens personnels du défunt). Les reliques fournissaient un symbol durable du défunt qui était susceptible de continuer de raconter et d'incarner des relations historiques, sociales et divines, en conservant le mana (pouvoir spirituel et puissance génératrice) de ceux qui étaient associées à elles. Hertz a aussi repéré l'importance du rituel pour restructurer et revitaliser la société. Pendant que les gens vivent l'expérience des rites de passage (séparation, transition et incorporation dulau groupe), la structure sociale et le sens des objets sont recréés. Les rites de passage, y compris ceux concernant la mort, autorisent un réajustement sociale et un rnouveau spirituel.

MotS-CLÉS : sépulture, mort, rituel funéraire, Hawai'i, reliques, art.

As I write this essay, the initial publication of Robert Hertz's seminal work on death is nearing its centenary (Hertz, 1907). My intent is to demonstrate the significance and continuing

\section{ABSTRACT}

This essay examines the process of death, deification and the production of relics in traditional Hawai'ian society in relationship to the work of Robert Hertz. Hertz elucidated the belief that death is not instantaneous, but rather a procedure that lasts until the body reaches a skeletal state. This process produces relics which can be potent objects that continue to benefit the living and allow limited communication with the deceased. In traditional Hawai'i, relics can be classified as primary relics (major bones), secondary relics (teeth, hair and smaller pieces of bone) and tertiary relics (personal possessions of the deceased). Relics provided a lasting symbol of the deceased that could continue to chronicle and embody historical, social and divine relations, while retaining the mana (spiritual power and generative potency) of those associated with it. Hertz also recognized the importance of ritual in restructuring and revitalizing society. As people and objects experience rites of passage (separation, transition and incorporation), social structure and object meaning is recreated. Rites of passage, including death, allow for social readjustment and spiritual renewal.

KeYwords: burial, death, funerary ritual, Hawai'i, relic, art relevance of Hertz's study of death by applying the basic theoretical underpinnings of his work to an analysis of traditional Hawai'ian funerary rituals. Western historical records for Hawai'i

* San Diego State University, tsowell@mail.sdsu.edu 
begin with Captain James Cook who arrived on the archipelago in 1778. My interest is in the religious system in place at that time, a system overturned in 1819 by Kamehameha II (Liholiho). After that pivotal event, Christianity began to flourish on the islands. Since local variations and historical change regarding funerary practices during this period are almost impossible to document, I refer to the era before 1819 as traditional.

During the traditional period in Hawai'i, the social system was highly stratified with chiefs (ali'i) possessing enormous amounts of mana (spiritual power and generative potency) that justified their elevated position. While all deaths were commemorated, the length and intensity of the rituals were determined by social and spiritual status. The death rituals for a ruling chief were the most important, elaborate and potentially dangerous. The process of death, deification and the production of relics in traditional Hawai'ian society is the focus of this essay.

\section{Theoretical Orientations}

Among the Hawai'ian chiefly class, death was viewed as a crucial rite of passage. Using the model proposed by Hertz, and built upon by Arnold van Gennep (1960) and Victor Turner (1969), rites of passage encompass three distinct phases: separation, transition and incorporation. Separation defines the (physical or symbolic) detachment of the individual from the social structure or a cultural condition. Transition is viewed as a liminal period in which the individual's status eludes normal classifications. This middle stage is unstable and less defined, as the individual passes through a state that is unlike the past or coming condition. Incorporation completes the passage as the individual moves back into a relatively stable state, but with a new status. This three part process enables individuals and society going through important changes to become whole again, albeit changed. The death of a member of society necessarily results in changed relationships, as the deceased enters a new stage of existence.

\section{Hawai'ian Worldview}

Traditionally, Hawai'ians understood themselves and their world in relation to the concepts of $A o$ and Po. Po was darkness, night, chaos, and the divine realm. It was from where all life originated and ultimately returned. Po was not a place, but rather a "state of existence" (Handy,
1927 : 69). Ao was light, day, order, and the human realm. All life and growth was the result of Po erupting into Ao (Gell, 1993 : 126; Hanson, 1982:344). Hawai'ians utilized a strategy of binding/containing and severing/releasing to deal with movement between $A o$ and $P o$ (Handy, 1927; Shore, 1989). Mana was the divine essence of $P o$ contained and bound within $A o$ until released. For a high chief, the body and its substances contained enormous amounts of mana. The skin acted as a barrier between the bound interior power and the outer world of $A o$. By wrapping and insulating the body, skin acted as a containment for spiritual power, and anything wrapped around the body could function in a similar way, including kakau (tattoo), kapa (barkcloth), and other ritual ornaments (Sowell, 1999). These wrappings empowered and protected the sacredness of the individual, expressing the kapu nature of the wearer's body.

For people and objects, a kapu designation indicated the presence of mana and thus the person or object had to be treated with proper care and respect. Kapu implied that a series of avoidance strategies were in place to protect bound up mana. Mana was always vulnerable, since it could be loosened, severed and released. Art and ritual were technologies that fostered the control of mana for human benefit, growth and regeneration. Mana uncontained in Ao was dangerous, unpredictable and chaotic. Thus, mana had to be contained, ordered, bound and protected by kapu. Kapu designated something as sacred, but it also indicated that a set of rules, regulations and social restrictions were in place to protect, contain and monitor the potential release and transfer of that spiritual power.

\section{Death}

In traditional Hawai'ian society, the process of death moved an individual from $A o$ (the world of the living) to Po (the spiritual realm). While all Hawai'ians went through the death cycle (separation, transition and incorporation), ritual observances concerning the death of an ali'i (chief) were much more complex and could last ten days or more, while the death of a commoner (maka'ainana) required much less ceremony and lasted from one to three days, depending on their status (Malo, 1951 : 96). Separation began with physical death, as the deceased became "poised to enter its discarnate phase of existence" (Handy et al., 1958:115). At this time the corpse was removed from normal living conditions and placed in a restricted and 
controlled area (Malo, 1951 : 97-99; see Hertz, 1960 : 30). While physical death began the release of the deceased's mana, it was not an immediate process. As Hertz noted $(1960: 34,36)$, the spirit of the deceased does not suddenly depart the body, but rather continues to belong to this world until the final funerary ritual.

In Hawai'i, after the body was separated from "normal life," the deceased entered the transitional phase of death as the bones were slowly revealed. For the death cycle to move forward, all fleshy materials (pela) had to be removed from the bones and thrown into the sea, although sometimes all or part the flesh could be buried or burned (Pukui et al., 1972 : 134, 143). For a ruling chief, this transitional or liminal period of the death process lasted approximately ten days while the body was buried in a shallow grave with a continuous fire above to promote the disintegration of the flesh (Malo, 1951 : 104-105).

During this transitional phase, as flesh decayed, the normal order of social life was thrown into turmoil, creating an unstable and uncertain situation. For the death of a ruling chief, the chiefly heir had to leave the district during this transition, but all other relatives remained. As the deceased chief's flesh decomposed, mana was slowly released, like a loosening net, creating a dangerous situation. With normal boundaries blurred, controls on social behavior became non-existent as mourners shared in "the actual state of the deceased" (Hertz, 1960 : 51). Social status and property rights were ignored. $K a p u$ were broken. Self-sacrifice was performed with acts of bloodletting, severing hair, knocking out teeth, scratching and scaring the skin (Cook, 1967: 599, 623, 1178, 1181; Frazer, 1922 : 420-427; Handy et al., 1958 : 156-157). Social fragmentation allowed mourners to interact with the deceased's released mana until the final funerary rites separated them again (Kamakau, 1964 : 34; Pukui et al., 1972 : 136; see Hertz, $1960: 39,51)$. At the end of this liminal ten day period for ruling chiefs, the bones were uncovered and any remaining flesh removed and properly disposed of (Malo, 1951 : 105). Hertz asserted that the time from death to final burial closely corresponds to the time a corpse takes to reach a skeletal condition, and that the condition of the body parallels the condition of the soul (Hertz, 1960 : 32, 45). Hertz also separated the "soul" of the deceased into two parts during the liminal phase, indicating that the "personality" of the deceased was unstable and wandering until the final funerary rites, while the "corporeal soul" remained within "the bones, hair, nails, etc." (Hertz, 1960 : 24). I will use the term "relic" to refer to the items Hertz defined as containing the corporeal soul.

After the flesh was removed and disposed of, the skeletal remains were ritually bound and properly deposited to enable the deceased's final movement into $P o$ (the spiritual realm), marking the final rite of incorporation (Kamakau, 1961: 214). While the treatment of skeletal remains varied, most bones were wrapped and bound into a fetal position and eventually buried in the earth, concealed in a cave or hidden in a crevice, often in a location deemed sacred to the deceased individual's lineage (Handy et al. 1958: 152; Kamakau, 1964 : 38; Pukui et al., 1972 : 134). For a ruling chief, the clean bones which contained powerful residual mana were wrapped in kapa and/or elaborate sennit "coffins" (Figure 1) and placed on the grounds of a heiau (sacred precinct) or other appropriate final resting place (Malo, 1951 : 105-106). Placing the remains somewhere familial or collective "brings about a profound change in the condition of the deceased; it delivers him from the isolation in which he was plunged since death, and reunites his body with those of his ancestors." (Hertz, 1960 : 55). For traditional Hawai'ians, this final ritual act allowed the deceased to enter the ancestral realm of $P o$.

After the final disposal of the deceased's remains, incorporation was complete. Once the ties between the living and the dead were disentangled and severed, the time of crises and uncertainty was over. If the death was that of a high chief, the deceased became deified at this point and the heir was allowed to return to the district with kapu restrictions again in place. As Hertz (1960 : 49) observed, the "death of a chief causes a deep disturbance in the social body" and a new chief cannot take over until the previous one has left the realm of the living, and that point is defined as the final funerary ceremony. Until decomposition was complete, Hertz explains "one is not really finished with the deceased, and his authority cannot be transmitted to his successor: the hand of the deceased can no longer hold the scepter, but it has not yet let go. One must wait for the King to be entirely dead before one can cry: Long live the King!" (Hertz, 1960 : 49)

While the end of the funerary process signaled the movement of the deceased into Po, by properly maintaining preserved bones and relics, the living were able to honor and communicate with the deceased beyond the period of final aggregation. In other words, while the deceased and the living were now fully separated, they were not completely removed. At the end of the funerary 


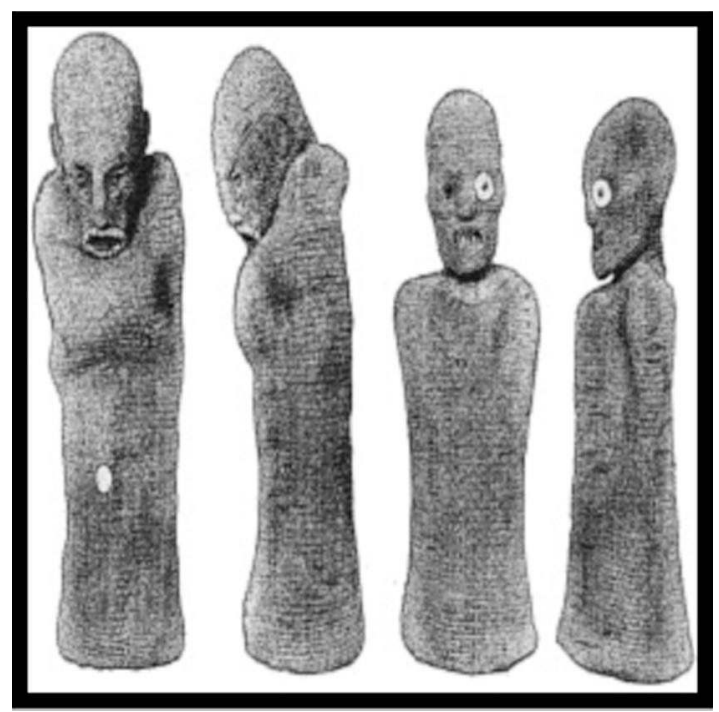

FIgURE 1. - Two sennit caskets ( $\left.k a^{\prime} a i\right)$ encasing the skeletal remains of deified chiefs. Transferred to the Bernice Pauahi Bishop Museum, Honolulu, by Prince Kuhio in 1918. Current whereabouts unknown (see Rose, 1992).

ritual, the deceased was henceforth able to visit the living for short periods of time when ritually called. Communication with the deceased was primarily achieved through the ritual manipulation of the deceased's relics.

\section{Relics}

According to Gregory Schopen (1998 : 256), relics are "things left behind." In traditional Hawai'ian society, three types of relics can be discerned. Primary relics were the major bones and skull of the deceased which were wrapped, bound and properly deposited (Figure 1). Access to primary relics was very restricted. Primary relics were often placed alongside other ancestral relics to create a concentrated place of worship and potential arena for spiritual access by descendants, priests (kahuna), or other parties. Secondary relics were teeth, hair and bits of bone that could be incorporated into objects to capture, contain and control some of the mana of the deceased, creating another important point of contact. Secondary relics were incorporated into figurative sculpture, bowls and creations of sennit and feather work (Figure 2), harnessing some of the mana of the deceased and creating communicative access between the world of the living $(A o)$ and the spiritual realm $(P o)$ for the new "owner."

In addition to primary and secondary relics directly obtained from the body, tertiary relics

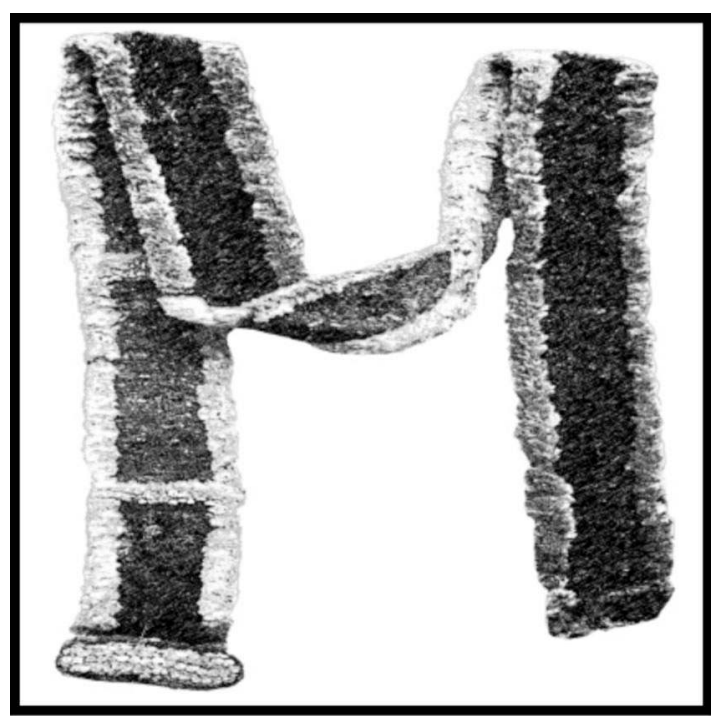

FIGURE 2. - Feather sash with human molars used for the investiture of a high chief. Bernice Pauahi Bishop Museum, Honolulu (see Rose, 1978)

were personal possessions of the deceased that could also contain enormous amounts of mana. While most of a deceased's mana was reincorporated into Po, some mana remained in the deceased's bones, hair, personal possessions and name (inoa) (Pukui et al., 1972 : 151). Some tertiary relics were placed with the bones when they were deposited at the end of the final burial ritual and allowed to decay. Other tertiary relics were passed on to the heir or other surviving family members of the appropriate status who were able to handle the responsibility and spiritual power contained within those objects. Secondary and tertiary relics had the potential to gain enormous amounts of power since they could be passed on, gaining additional mana with subsequent owners and with further ritual use. Over time these more portable relics, often incorporated into sculptures and objects, developed their own genealogies and histories, gaining enormous amounts of mana in the process. Secondary and tertiary relics were powerful symbols that chronicled historical, social and divine relations, while retaining the mana of those associated with them.

While social status was primarily determined by genealogy, some movement was possible through skill, charisma and the savvy manipulation of position. Thus, continual legitimization of status was key and was partly achieved through the possession of relics. Especially during the transition from one chief to the next, visual symbols were powerful and necessary 
reminders of rightful genealogical succession. The body of a high chief was the ultimate symbol of social order, prosperity and continuity. When a high chief died and the body or "symbol" decayed, the problem was solved by using relics as an enduring symbol of the deceased. The heir became the "keeper" of these symbols and benefited from their power to help maintain continuity and social order. Thus the body of the deceased chief was replaced with more permanent and stable relics to reinforce political, social and spiritual order. The movement from body to object allowed for greater permanence. Through immobilization, relics became lasting symbols expressing genealogical succession and legitimacy.

After 1820, when Christian burials started to be adopted, relics diminished in importance. Those in circulation came to be viewed as sentimental mementos of the deceased rather than sources of power and spiritual contact. The relic as an enduring symbol of a ruling chief's body or essence waned as the Hawai'ian monarchy turned to a more Westernized and Christianized form of power structure. Increasingly viewed as devoid of power, many secondary and tertiary relics were eventually traded, sold or given away in the nineteenth century. Traditional beliefs remained stronger among the lower classes, but by the middle of the nineteenth century, conversion to Christianity was widespread, forever changing concepts of death and the power of traditional Hawai'ian relics.

\section{Conclusion}

Hertz's contribution to the understanding of death is profound and enduring. He elucidated the belief that death is not instantaneous, but rather a process that lasts until the body reaches a skeletal state, and that death is not "mere destruction but a transition" or rite of passage (Hertz, 1960 : 48). He also linked transitory ideas of death to the corpse, the soul and the mourners, stating "there is a natural connection between the beliefs concerning the disintegration of the body, the fate of the soul, and the state of the survivors during that same period" (Hertz, $1960: 53$ ). The result of the funerary process was "to give burial to the remains of the deceased, to ensure the soul peace and access to the land of the dead, and finally to free the living from the obligations of mourning" (Hertz, 1960 : 54). Hertz also pointed to the importance of relics as powerful objects that connected the deceased with the world of the living (Hertz, $1960: 57,72$ ).
He recognized the importance of ritual in restructuring and revitalizing society. Natural death was not enough. "In establishing a society of the dead, the society of the living regularly recreates itself"' (Hertz, 1960 : 72). As people and objects experience rites of passage (separation, transition and incorporation), social structures and object meanings are recreated. Rites of passage, including death, allow for social readjustment and spiritual renewal.

\section{BIBLIOGRAPHY}

Cook James, 1967. The Journals of Captain James Cook on His Voyages of Discovery, J.C. Beaglehole (ed), Volume 3, Cambridge University Press for the Hakluyt Society.

Frazer James George, 1922. The Belief in Immortality and the Worship of the Dead, Volume 2, Trinity College, Cambridge, Messrs Macmillian \& Co. Ltd.

Gell Alfred, 1993. Wrapping in Images: Tattooing in Polynesia, New York, Oxford University Press.

Handy E. S. Craighill, 1927. Polynesian Religion, Honolulu, Bishop Museum Press.

Handy E. S. Craighill and Mary Kawena Pukui, 1958. The Polynesian Family System in $\mathrm{Ka}$-' $u$ Hawai'i, Rutland, Vermont, Charles E. Tuttle Company.

Hanson F. Allan, 1982. Female Pollution in Polynesia?, Journal of the Polynesian Society 91, pp. 335381 .

Hertz Robert, 1907. Contribution à une étude sur la représentation collective de la mort, Année sociologique 10 , pp. 48-137.

Hertz Robert, 1960. Death and the Right Hand, translated by Rodney and Claudia Needham, Glencoe, Illinois, The Free Press.

Kamakau Samuel Manaiakalani, 1961. Ruling Chiefs of Hawaii, Honolulu, The Kamehameha Schools Press.

Kamakau Samuel Manaiakalani, 1964. Ka Po'e Kahiko (The People of Old), originally published 1866-1871, Honolulu, Bishop Museum Press.

Malo David, 1951. Hawaiian Antiquities (Moolelo Hawaii), translated by Nathaniel B. Emerson in 1898, Honolulu, Bishop Museum Press.

Pukui Mary Kawena, E.W. HAErTig and Catherine A. LEE, 1972. Nana I Ke Kumu (Look to the Source), Volume 1, Honolulu, Hui Hanai.

Rose Roger, 1978. Symbols of Sovereignty: Feather Girdles of Tahiti and Hawai'i, Honolulu, Bishop Museum Press.

_, 1992. Reconciling the Past: Two Basketry Ka'ai and the Legendary Liloa and Lonoikamakahiki, Honolulu, Bishop Museum Press. 
Schopen Gregory, 1998. Relic, in M. Taylor (ed), Critical Terms for Religious Studies, Chicago, University of Chicago Press, pp. 256-268.

ShORE Bradd, 1989. Mana and Tapu, in A. Howard and R. Borofsky (eds), Developments in Polynesian Ethnology, Honolulu, University of Hawaii Press, pp. 137-173.

Sowell Teri, 1999. From Darkness to Light: Art and the Hawaiian Theory of the Body, Unpublished
Ph.D. Dissertation, Indiana University (Bloomington).

TURNER Victor, 1969. The Ritual Process: Structure and Anti-Structure, Chicago, Aldine Publishing Company.

Van Gennep Arnold, 1960. The Rites of Passage, Chicago, University of Chicago Press. 